\title{
Ground beetles (Coleoptera, Carabidae) of the central part of the Badzhal Range, Khabarovskii Krai, Russia
}

\section{ЖКужекиџы (Coleoptera, Carabidae) центральной части Баджальского хребта, Хабаровский край}

\author{
Yu.N. Sundukov*, O.V. Kuberskaya** \\ Ю.Н. Сунауков*, О.В. Куберская**
}

\begin{abstract}
* Federal Scientific Center of the East Asia Terrestrial Biodiversity, Far East Branch of the Russian Academy of Sciences, Prosp. 100-letiya Vladivostoka 159, Vladivostok690022 Russia. E-mail: yun-sundukov@mail.ru.

* Федеральный научный центр биоразнообразия наземной биоты Восточной Азии ДВО РАН, пр. 100-летия Владивостока 159 , Владивосток 690022 Россия.

** Komsomolsky branch of Federal State-Funded Institution «Zapovednoye Priamurye», Prosp. Mira 54, Komsomolsk-na-Amure 681000 Russia. E-mail: leonika-00@mail.ru.

** Филиал Комсомольский ФГБУ «Заповедное Приамурье», пр-т Мира 54, Комсомольск-на-Амуре 681000 Россия.
\end{abstract}

Key words: Carabidae, fauna, Badzhal Range, Russian Far East.

Ключевые слова: Carabidae, фауна, Баджальский хребет, Дальний Восток России.

\begin{abstract}
A list of 76 Carabidae species from 21 genera is presented for the central part of the Badzhal Range, Khabarovskii Krai, Russia on the basis of an examination of c. 2000 specimens. The altitudinal-zonal distribution of ground beetle populations along the Omot-Makit River basin in central part of the ridge is analyzed. Representatives of the genera Pterostichus and Carabus are predominate in the zonal biotopes. The fauna of carabid beetles of the Badzhal Range is characterized as "Arctic-montane» according to the generic composition, with a high number of East Asian boreal-montane endemic species.
\end{abstract}

Резюме. На основании литературных данных и изучении более 2 тысяч экземпляров, впервые составлен список Carabidae Баджальского хребта, включающий 76 видов из 21 рода. Проанализировано высотно-поясное население жужелиц в бассейне р. Омот-Макит (центральная часть хребта). Показано, что численно в зональных биотопах этой реки доминируют представители родов Pterostichus и Carabus. Таксономический анализ показывает, что на уровне родовых групп карабидофауна Баджальского хребта имеет ярко выраженные черты арктомонтанной фауны, обогащенной значительной долей восточноазиатских бореомонтанных эндемиков видового уровня.

\section{Introduction}

The Badzhal Range is one of the southern and highest ridges of the Amur Region [Gvozdecki, Golubchikov, 1987], located in the interfluve of the Amur and Amgun rivers, 200-220 km to the north of Khabarovsk (Fig. 1). Its length from the southwest to the northeast is about $220 \mathrm{~km}$, and the maximum heights exceed 2000 m altitude (Mt. Korol, 2263 m; Mt. Ulun, 2221 m; Mt. Koroleva, $2219 \mathrm{~m}$ ). According to one of the floristic zoning schemes, along the southern foothills of the Badzhal Radge there is a border between the Manchuri- an province of the East Asian floristic region and the Okhotsk-Kamchatka province of the Circumboreal floristic region [Mishina, 2003].

Despite the fact that in the second half of the 20th century and the beginning of the 21 st century, the collection of ground beetles on the Badzhal Range was quite active, there are almost no publications on the collected material. For example, we know that in the foothills of the Badzhal Range and the Amgun River valley small collections of ground beetles were made by A.I. Kurentsov and D.G. Kononov in 1957, O.G. Gamerova, A.S. Pleshanov, A.V. Tokmakov and V.I. Epova in 1983, M.E. Cherniakhovsky in 1984 and A.A. Kuzmin in 1995. Interesting materials on Carabidae were collected in the highlands of the ridge by the famous geologist and entomologist O.N. Kabakov (1965) and ornithologist A.A. Nazarenko (1978 and 1979). The fruitful year for studying the fauna of Badzhal Range was 1997, when five coleopterologists worked at once on its territory: A.E. Brinev, V.A. Komarov and theriologist S.V. Kruskop (the Mogdy River basin in the western part of the ridge) and D.E. Lomakin, A.V. Plutenko and Yu.N. Sundukov (Gerbi River basin in the central part). In our century, the highlands of this ridge were visited by entomologists E.V. Novomodnyi (2001), D.N. Kochetkov (2007), A.E. Brinev and P.V. Budilov (2014). However, according to literary data from the Badzhalsky Range and the Amgun River valley only 20 species from 10 genera of the family Carabidae were indicated, and 6 of them were described as new taxa [Lafer, 1978, 1989; Shilenkov, 1987; Obydov, 1999, 2005; Brinev, Shilenkov, 2001; Zamotajlov, Lafer, 2001; Plutenko, 2004; Sundukov, 2005, 2011, 2013, 2019; Zamotajlov, 2005, 2017; Dudko, 2006; Brinev, Budilov, 2007; Koshkin et al., 2016; Deuve, Reuter, 2019]. 


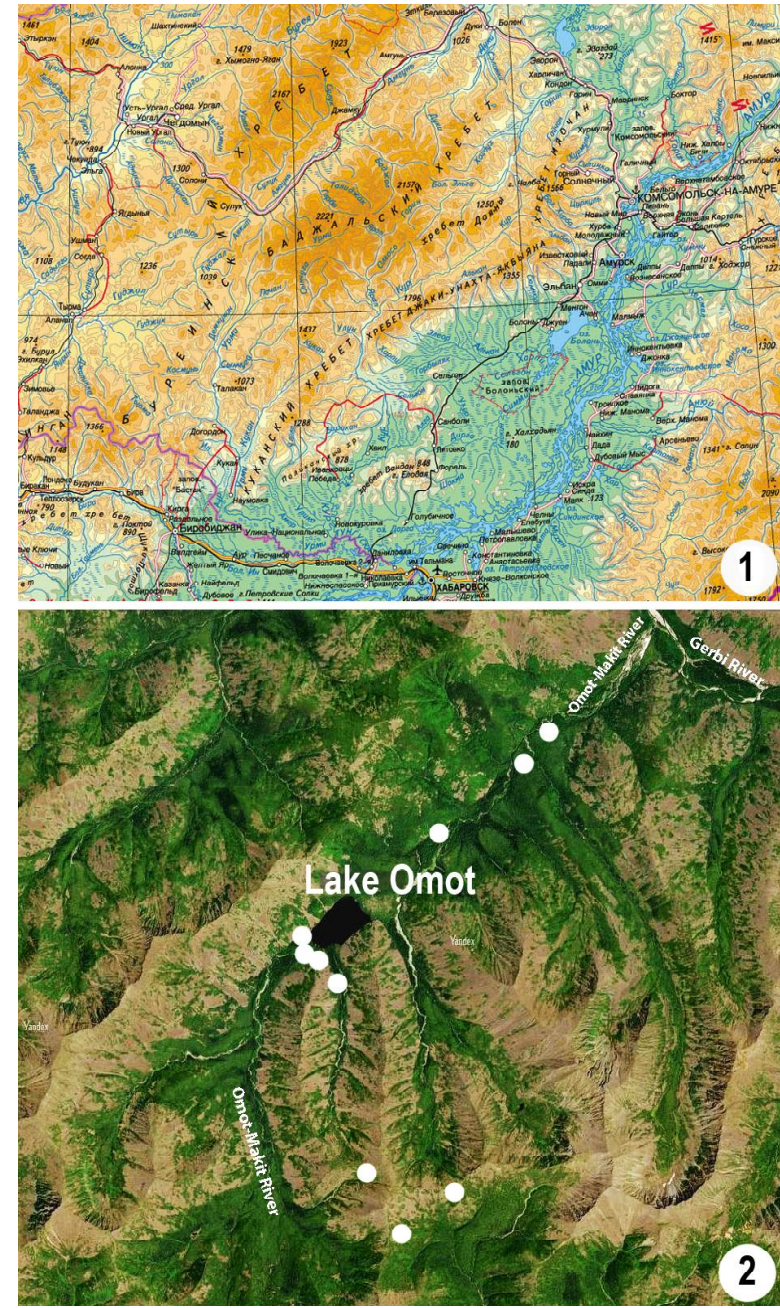

Figs 1-2. 1 - Badzhal Range on the map of the Amur Region; 2 - Map of the Omot-Makit River basin. White circles indicate the location of soil traps. The map was received from the site https://yandex.ru/maps/.

Рис. $1-2.1$ - Баджальский хребет на карте Приамурья; 2 - карта бассейна р. Омот-Макит. Белые кружки указывают расположение почвенных цовушек. Карта получена с сайта https://yandex.ru/maps/.

Unfortunately, we are not able to study all the material collected by the listed collectors. But, given the scarce information on the carabid fauna of the Badzhal Range (as a whole for the mountains of the Northern Amur region), we consider it to be useful to publish a list of ground beetles of this region, based on literature data and materials studied by the first author to date.

\section{Research area}

The studies were conducted in 1997 in the Gerbi River basin, located in the central, highest part of the Badzhal Range (Fig. 1, 8). Since the main collection of ground beetles were made in the Omot-Makit River basin, the following is the description of the natural conditions of this region only (Figs 2-7).
The vertical zonation in the central part of Badzhal Range is well defined. In the Omot-Makit River basin two high-altitude zones of vegetation - mountain-forest and mountain-tundra are clearly distinguished.

The mountain forest zone (900-1600 m alt.) occupies the valleys of the Omot-Makit River and its tributaries, as well as the adjacent slopes. It is represented by three main formations: 1) floodplain spruce forests with the addition of fir and poplar (900-1300 m alt.); 2) swampy valley larch forests rising along streams to $1500-1600 \mathrm{~m}$ alt.; 3) mountain larch forests on the slopes, sometimes reaching a heigh of $1700 \mathrm{~m}$ altitude.

The mountain-tundra zone occupies the upper part of the watersheds and plateau above 1700-1800 m altitude and is represented by small sections of the ArcticAlpine shrubbery or moss-lichen tundra with significant participation of dwarf stone pine. From the foot of the slopes to the watersheds, large areas are occupied by placer stones, the development of which is associated with the influence of systematic wild fires [Man'ko, 1961].

In the middle course of Omot-Makit River, at an altitude of $1155 \mathrm{~m}$, there is a fairly big Lake Omot, an area of about $0.3 \mathrm{~km}^{2}$ (Figs 4,7 ). It is believed that the lake arose as a result of a powerful seismic collapse of the mountain slope.

\section{Material and methods}

The collection of the first author that was made July 2-4, 1997 in the lower and middle reaches of Gerbi River and July 5-21 of the same year - in the basin of its left tributary, Omot-Makit River was the basis for this work (Fig. 2). During this time, 1964 specimens of adults of ground beetles belonging to 71 species from 17 genera and 13 tribes were collected and studied. The bulk of this material is stored in the collection of the Federal Scientific Center of the East Asia Terrestrial Biodiversity, Far Eastern Branch of the Russian Academy of Sciences, Vladivostok (FEB). In addition, the materials of E.V. Novomodnyi (collected in 2001 in Omot-Makit River basin), D.N. Kochetkov (in 2007, at the source of Omot River) and a few specimens from the collections of the FEB, Moscow State Pedagogical University and Zoological Institute of the Russian Academy of Sciences, St. Petersburg (a total 49 specimens of 19 species). Taking into account the literature data, the general list of ground beetles of Badzhal Range in this work includes 76 species from 21 genera and 15 tribes.

In the study of ground beetles, we used the most affordable methods: manual collection, collection using an exhauster and trapping in soil traps. As soil traps, $200 \mathrm{ml}$ plastic glasses filled with a $2-4 \%$ aqueous solution of acetic acid were used.

The taxonomic sequence of subfamilies and tribes in the list is given according to their position in the catalogue of the ground beetles of Sikhote-Alin [Sundukov, 2013], and genera, subgenera within the genus and species within the subgenus, in alphabetical order. 
The frequently cited collector name of Yu. Sundukov in the labels for the material is abbreviated as YS.

\section{List of species}

\section{Carabidae Latreille, 1802 \\ Cicindelinae Latreille, 1802 \\ Cicindelini Latreille, 1802 \\ Cicindela (Cicindela) restricta \\ Fischer von Waldheim, 1828}

Cicindela (Cicindela) restricta Fischer von Waldheim, 1828: Lafer, 1978: 9-10 (Badzhal River; Amgun River near Duki; Amgun River near Pupok Mt.).

Material. Omot-Makit River, h 900-1000 m, 2425.VI.2001, E. Novomodnyi leg., 3 ex.; source of Omot River (Urmi River basin), h $2000 \mathrm{~m}$, tundra, 10-13.VII.2007, D. Kochetkov leg., 3 ex.

\section{Cicindela (Cicindela) transbaicalica Motschulsky, 1844}

Cicindela (Cicindela) transbaicalica Motschulsky, 1844: Lafer, 1978: 14 (Amgun River near Pupok Mt.).

Nebriinae Laporte, 1834

Nebriini Laporte, 1834

Leistus (Leistus) niger Gebler, 1847

Leistus (Leistus) niger Gebler, 1847: Sundukov, 2013: 48 (Badzhal Range).

Material. Middle course of Gerbi River, h 700-800 m 3-4.VII.1997, YS, 13 ex.; $3 \mathrm{~km}$ above the mouth of OmotMakit River, h $1000 \mathrm{~m}$, dark coniferous valley forest, 5.VII.1997, YS, 4 ex.; Omot-Makit River 2 km below Lake Omot, h 1100 m, floodplain dark coniferous forest, 1521.VII.1997, YS, 4 ex.; Lake Omot, h 1170 m, floodplain dark coniferous forest, 9-15.VII.1997, YS, 5 ex.; Omot-Makit River from Omot Lake to the upper reaches, h 1170-1400 m, 7-9.VII.1997, YS, 1 ex.; the upper reaches of Urmi River, h 1500 m, VI.1978, A. Nazarenko leg., 1 ex.

\section{Nebria (Boreonebria) biseriata Lutshnik, 1915}

Material. Lake Omot, h $1170 \mathrm{~m}$, valley coniferous forest, 8-13.VII.1997, YS, 2 ex.; ibid, 9-15.VII.1997, YS, 7 ex.; ibid 13-20.VII.1997, YS, 43 ex.; ibid, 25.VI.2001, E. Novomodnyi leg., 2 ex.; the upper reaches of Omot-Makit River, h 1180$1400 \mathrm{~m}$, dark coniferous forest, 7-9.VII.1997, YS, 10 ex.; Badzhal Range, h 1800-2000 m, anonymous, 1 ex.

\section{Nebria (Boreonebria) frigida R.F. Sahlberg, 1844}

Material. Middle course of Gerbi River, h 700-900 m, 34.VII.1997, YS, 17 ex.; $3 \mathrm{~km}$ above the mouth of Omot-Makit River, h $1000 \mathrm{~m}$, dark coniferous valley forest, 5.VII.1997, YS, 31 ex.; Omot-Makit River $3 \mathrm{~km}$ below Lake Omot, h $1050 \mathrm{~m}$ 6.VII.1997, YS, 4 ex.; ibid, 12.VII.1997, YS, 2 ex.; Omot-Makit River $2 \mathrm{~km}$ below Lake Omot, h 1100 m, floodplain dark coniferous forest, 15-21.VII.1997, YS, 4 ex.; Lake Omot, h $1170 \mathrm{~m}$, floodplain dark coniferous forest, 9-15.VII.1997, YS, 152 ex.; ibid, 13-20.VII.1997, YS, 23 ex.; source of Omot River, h 1800-2000 m, mountain tundra, 7-19.VII.1997, YS, 1 ex.; tundra, 25.VI 2001, E. Novomodnyi leg., 1 ex.

\section{Nebria (Boreonebria) gyllenhali (Schönherr, 1806)}

Material. Middle course of Gerbi River, h $700-800 \mathrm{~m}$, 3-4.VII.1997, YS, 8 ex.; Omot-Makit River from Lake Omot up to $3 \mathrm{~km}$ downstream, h 1050-1170 m, 6.VII.1997, YS,
3 ex.; Lake Omot, h 1170 m, floodplain dark coniferous forest, 9-15.VII.1997, YS, 5 ex.

\section{Nebria (Boreonebria) nivalis (Paykull, 1790)}

Material. Middle course of Gerbi River, h $700-800 \mathrm{~m}$, bank of the river, 3-4.VII.1997, YS, 2 ex.; Omot-Makit River 2 $\mathrm{km}$ below Lake Omot, h 1100 m, 5.VII.1997, YS, 6 ex.; OmotMakit River from Lake Omot up to $3 \mathrm{~km}$ downstream, h 1050-1170 m, 12.VII.1997, YS, 10 ex.; Lake Omot, h 1180 m, on the bank of a stream, 9-15.VII.1997, YS, 1 ex:; the upper reaches of Omot-Makit River, $\mathrm{h} \sim 1200-1500 \mathrm{~m}$, bank of the river, 7.VII.1997, YS, 1 ex.; source of Omot River, h 2000$2100 \mathrm{~m}$, dwarf stone pine tundra, 7-19.VII.1997, YS, 19 ex.; the upper reaches of Urmi River, h 1700-2000 m, anonymous, $1 \mathrm{ex}$.

\section{Nebria (Boreonebria) subdilatata Motschulsky, 1844}

Material. Middle course of Gerbi River, h $700-800 \mathrm{~m}$, pebble bank of river, 3-4.VII.1997, YS, 4 ex.; Omot-Makit River $3 \mathrm{~km}$ below Lake Omot, h 1050 m, 6.VII.1997, YS, 1 ex.; ibid, 12.VII.1997, YS, 2 ex.

\section{Nebria (Catonebria) baicalopacifica Dudko et Shilenkov, 2006}

Nebria (Catonebria) baicalopacifica Dudko et Shilenkov, sp.n.: Dudko, 2006: 26 (the upper reaches of the Omot-Makit River).

Material. Middle course of Gerbi River, h $800 \mathrm{~m}$, pebble bank of river, 4.VII.1997, YS, 1 ex.; source of Omot River, tundra, 25.VI.2001, E. Novomodnyi leg., 2 ex.

\section{Nebria (Catonebria) catenulata Fischer von Waldheim, 1820}

Nebria (Catonebria) catenulata Fischer von Waldheim, 1820: Dudko, 2006: 21 (Gerbi River 12 km SE of Gerbi; lower course of the Omot-Makit River; Dzhamku River).

Material. Middle course of Gerbi River, h $800 \mathrm{~m}$, pebble bank of river, 4.VII.1997, YS, 3 ex.; lower course of OmotMakit River, h 900-1000 m, 5.VII.1997, YS, 5 ex.; OmotMakit River from Lake Omot up to $3 \mathrm{~km}$ downstream, h 1050-1170 m, 12.VII.1997, YS, 1 ex.

\section{Nebria (Reductonebria) ochotica R.F. Sahlberg, 1844}

Material. Middle course of Gerbi River, h 700-800 m, pebble bank of river, 3-4.VII.1997, YS, 8 ex.; Omot-Makit River $2 \mathrm{~km}$ below Lake Omot, h $1100 \mathrm{~m}$, bank of the river, 15-21.VII.1997, YS, 9 ex.; Omot-Makit River from Lake Omot up to $3 \mathrm{~km}$ downstream, h 1050-1170 m, 12.VII.1997, YS, 22 ex.; Omot-Makit River from Omot Lake to the upper reaches, h 1170-1400 m, 7-9.VII.1997, YS, 7 ex.

\section{Notiophilini Motschulsky, 1850}

Notiophilus fasciatus Mäklin, 1855

Material. $3 \mathrm{~km}$ above the mouth of Omot-Makit River, h $1000 \mathrm{~m}$, dark coniferous valley forest, 5.VII.1997, YS, 1 ex.; Omot-Makit River from Lake Omot up to $3 \mathrm{~km}$ downstream, h 1050-1170 m, 6.VII.1997, YS, 2 ex.; ibid, 12.VII.1997, YS, 1 ex; Omot-Makit River $2 \mathrm{~km}$ below Lake Omot, h $1100 \mathrm{~m}$, floodplain dark coniferous forest, 15-21.VII.1997, YS, 17 ex.; Lake Omot, $\mathrm{h} 1180 \mathrm{~m}$, larch forest at the foot of the slope, 8-13.VII.1997, YS, 12 ex.; ibid, h $1170 \mathrm{~m}$, floodplain dark coniferous forest, 9-15.VII.1997, YS, 22 ex.; ibid, 1320.VII.1997, YS, 11 ex.; Omot-Makit River from Omot Lake 

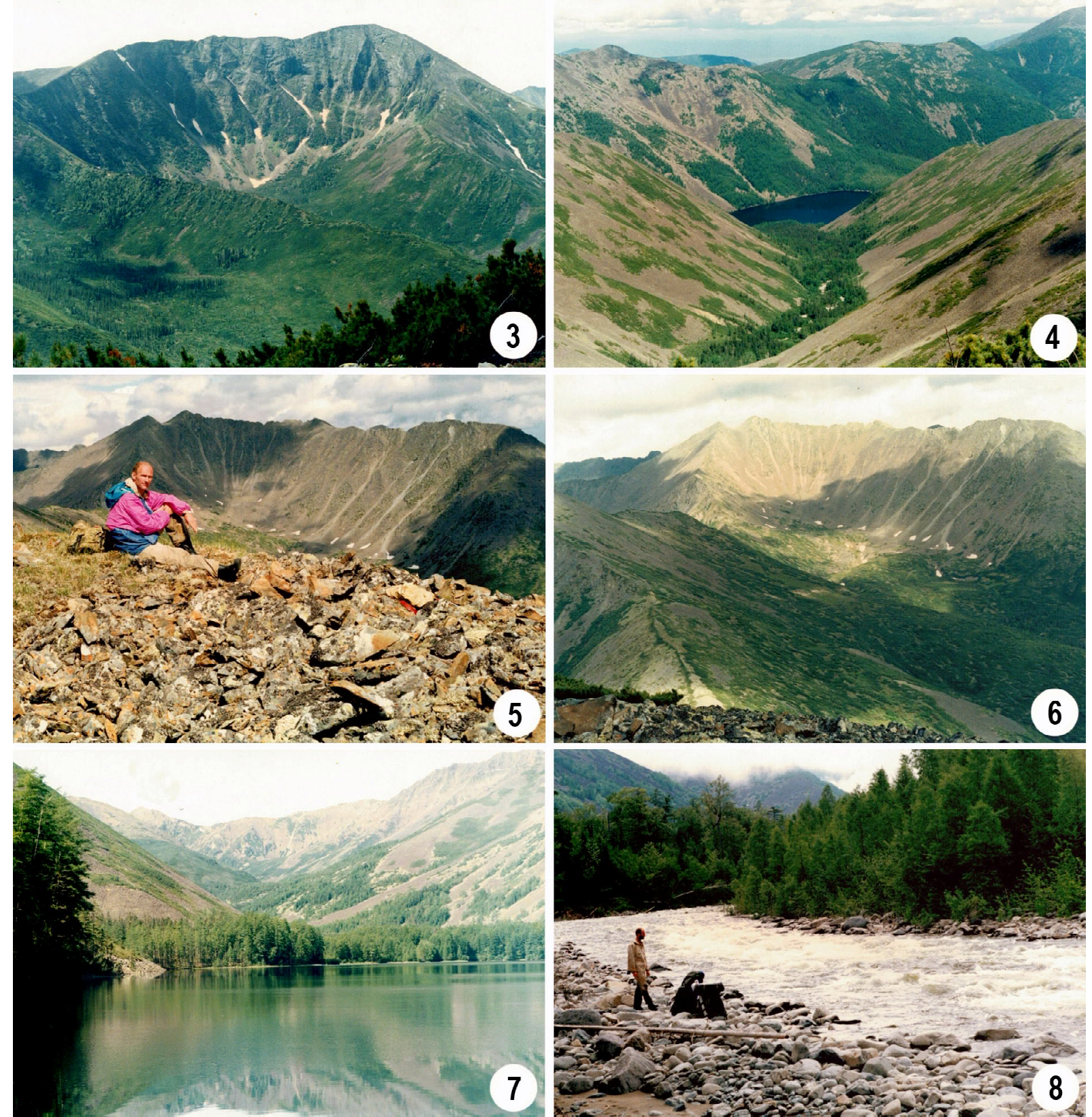

Figs 3-8. Habitats of Carabidae in Badzhal range. 3 - The source of the Omot River; 4 - View of the Lake Omot from the watershed of the Omot and Omot-Makit rivers; 5 - Placer stones in the foreground - the habitat of Pterostichus orion, Pt. longipes and Pt. (Cryobius) sp. 4; 6 - View of the Ulun Mt., $2221 \mathrm{~m}$ alt.; 7 - The Lake Omot; 8 - The Gerbi River in the middle reaches. Photos by A.V. Plutenko.

Рис. 3-8. Местообитания жужелиц Баджальского хребта. 3 - Исток р. Омот-Макит; 4 - вид на оз. Омот с водораздела рек Омот и Омот-Макит; 5 - каменные россыпи на переднем плане - биотоп Pterostichus orion, Pt. Longipes and Pt. (Cryobius) sp. 4; 6 - виА на гору Улун, 2221 м н.у.м.; 7 - оз. Омот; 8 - р. Герби в среднем течении. Фото А.В. Пиутенко.

to the upper reaches, h 1170-1400 m, 7-9.VII.1997, YS, 1 ex.; source of Omot River, h-2000-2100 m, dwarf stone pine tundra, 7-19.VII.1997, YS, 24 ex.

Carabinae Latreille, 1802

Carabini Latreille, 1802

Carabus (Aulonocarabus) canaliculatus sichotensis Born, 1914

Carabus (Aulonocarabus) canaliculatus sichotensis Born, 1914: Sundukov, 2013: 55 (Badzhal Range).
Material. Middle course of Gerbi River, h $700-750 \mathrm{~m}$, floodplain poplar forest, 3.VII.1997, YS, 1 ex.; $3 \mathrm{~km}$ above the mouth of Omot-Makit River, h $1000 \mathrm{~m}$, dark coniferous valley forest, 5.VII.1997, YS, 13 ex.; Omot-Makit River 2 km below Lake Omot, $\mathrm{h} 1100 \mathrm{~m}$, floodplain dark coniferous forest, 15-21.VII.1997, YS, 19 ex.; Lake Omot, h 1180 m, larch forest at the foot of the slope, 8-13.VII.1997, YS, 4 ex.; ibid, h $1170 \mathrm{~m}$, floodplain dark coniferous forest, 915.VII.1997, YS, 26 ex.; ibid, 13-20.VII.1997, YS, 3 ex.; source of Omot River, h $2000-2100 \mathrm{~m}$, dwarf stone pine tundra, 7-19.VII.1997, YS, 3 ex. 
Carabus (Aulonocarabus) gaschkewitschii gaschkewitschii Motschulsky, 1859

Carabus (Aulonocarabus) gaschkewitchi gaschkewitchi Motschulsky, 1859: Brinev, Budilov, 2007: 29 (Badzhal Range). Deuve, Reuter, 2019: 6 (Badzhal Range).

Material. Source of Omot River, h 2000-2100 m, dwarf stone pine tundra, 7-19.VII.1997, YS, 24 ex.; ibid, h 18002000 m, mountain tundra, 14-19.VII.1997, YS, 90 ex.; source of Omot River (Urmi River basin), h $2000 \mathrm{~m}$, tundra, 1013.VII.2007, D. Kochetkov leg., 7 ex.

\section{Carabus (Aulonocarabus) kabakovi Lafer, 1989}

Carabus kabakovi: Lafer, 1989: 119 (the upper reaches of the Dariya River; Talijak Plateau; the upper reaches of the Urmi River).

Carabus (Aulonocarabus) kabakovi Lafer, 1989: Koshkin et al., 2016: 313 (Badzhal Range).

Material. Source of Omot River, h 2000-2100 m, dwarf stone pine tundra, 7-19.VII.1997, YS, 2 ex.; ibid, h 1800$2000 \mathrm{~m}$, mountain tundra, 14-19.VII.1997, YS, 9 ex.; the upper reaches of Dariya River, VIII 1965, O. Kabakov leg., 1 ex.; the upper reaches of Urmi River, h 1700-2000 m, mountain tundra, 18.VI.1979, A. Nazarenko leg., 1 ex.

\section{Carabus (Hemicarabus) macleayi Dejean, 1826}

Carabus (Hemicarabus) macleayi Dej.: Shilenkov, 1987: 8 (Amgun station).

Material. Middle course of Gerbi River, h 700 m, bank of the river, 3.VII.1997, YS, 1 ex.

Carabus (Megodontus) vietinghoffii fulgidus Fischer von Waldheim, 1828

Carabus (Megodontus) vietinghoffi bureianus Shilenkov, 1996: Obydov, 1999: 92 (Lake Omot), 2005: 23 (Lake Omot).

Material. Middle course of Gerbi River, h $800 \mathrm{~m}$, floodplain forest, 4.VII.1997, YS, 1 ex:; $3 \mathrm{~km}$ above the mouth of Omot-Makit River, $\mathrm{h} \sim 1000 \mathrm{~m}$, dark coniferous valley forest, 5.VII.1997, YS, 1 ex.; Omot-Makit River $2 \mathrm{~km}$ below Lake Omot, h 1100 m, floodplain dark coniferous forest, 1521.VII.1997, YS, 15 ex.; Lake Omot, h $1180 \mathrm{~m}$, larch forest at the foot of the slope, 8-13.VII.1997, YS, 12 ex.; ibid, h $1170 \mathrm{~m}$, floodplain dark coniferous forest, 9-15.VII.1997, YS, 3 ex.; source of Omot River, h 2000-2100 m, dwarf stone pine tundra, 7-19.VII.1997, YS, 16 ex.; source of Omot River (Urmi River basin), h $2000 \mathrm{~m}$, mountain tundra, 1013.VII.2007, D. Kochetkov leg., 1 ex.

\section{Carabus (Tomocarabus) aurocinctus Motschulsky, 1844}

Material. $3 \mathrm{~km}$ above the mouth of Omot-Makit River, h 1000 m, dark coniferous valley forest, 5.VII.1997, YS, 9 ex.; Omot-Makit River $2 \mathrm{~km}$ below Lake Omot, h 1100 m, floodplain dark coniferous forest, 15-21.VII.1997, YS, 13 ex.

Elaphrinae Latreille, 1802

Elaphrini Latreille, 1802

Blethisa multipunctata (Linnaeus, 1758)

Material. Lower course of Gerbi River, h 650 m, sphagnum swamp, 2-3.VII.1997, YS, 3 ex.

\section{Elaphrus (Elaphroterus) angusticollis R.F. Sahlberg, 1844}

Material. Middle course of Gerbi River, h $800 \mathrm{~m}$, coniferous forest, 3.VII.1997, YS, 4 ex.; $3 \mathrm{~km}$ above the mouth of Omot-Makit River, h $1000 \mathrm{~m}$, bank of a forest stream, 5.VII.1997, YS, 9 ex.

\section{Elaphrus (Elaphrus) riparius \\ (Linnaeus, 1758)}

Material. Lake Omot, h $1170 \mathrm{~m}$, silted shore, 813.VII.1997, YS, 1 ex.; ibid, 13-20.VII.1997, YS, 2 ex.; ibid, small lake among dwarf stone pine, 25.VI 2001, E. Novomodnyi leg., 1 ex.

\section{Elaphrus (Neoelaphrus) sibiricus} Motschulsky, 1844

Material. Lake Omot, $\mathrm{h} \sim 1170 \mathrm{~m}$, silted shore, 1320.VII.1997, YS, 2 ex.

Broscinae Hope, 1838

Broscini Hope, 1838

Miscodera arctica (Paykull, 1798)

Material. Omot-Makit River from Lake Omot up to $3 \mathrm{~km}$ downstream, h 1050-1170 m, bank of the river, 6.VII.1997, YS, 1 ex.

Trechinae Bonelli, 1810

Trechini Bonelli, 1810

Trechus (Trechus) badzhalicus Plutenko, 2004

Trechus badzhalicus: Plutenko, 2004: 33 (environs of the Lake Omot).

Trechus (Trechus) badzhalensis Plutenko, 2004: Sundukov, 2019: 1051 (Badzhal Range).

Tachyini Motschulsky, 1862

Tachyta (Tachyta) nana (Gyllenhal, 1810)

Material. Omot-Makit River $2 \mathrm{~km}$ below Lake Omot, h 1100 m, 5.VII.1997, YS, 6 ex.; Omot-Makit River from Lake Omot up to $3 \mathrm{~km}$ downstream, h 1050-1170 m, 6.VII.1997, YS, 15 ex.; ibid, 12.VII.1997, YS, 13 ex.

Bembidiini Stephens, 1827

Bembidion (Bembidion) mandli Netolitzky, 1932

Material. Lake Omot, h $1170 \mathrm{~m}$, coastal glades, 1320.VII.1997, YS, 4 ex.

\section{Bembidion (Blepharoplataphus) hastii C.R. Sahlberg, 1827}

Material. Omot-Makit River from Lake Omot up to $3 \mathrm{~km}$ downstream, h 1050-1170 m, pebble bank of river, 6.VII.1997, YS, 4 ex.

\section{Bembidion (Diplocampa) transparens prostratum} (Motschulsky, 1844)

Material. Lower course of Gerbi River, h $\sim 600$ m, swampy puddles on the road, 2.VII.1997, YS, 2 ex.

\section{Bembidion (Eupetedromus) sibiricum Dejean, 1831}

Material. Lower course of Gerbi River, h $\sim 600 \mathrm{~m}$, swampy puddles on the road, 2.VII.1997, YS, 4 ex.; Lake Omot, h $1170 \mathrm{~m}$, silted shore, 13-20.VII.1997, YS, 13 ex.

\section{Bembidion (Melomalus) altaicum (Gebler, 1833)}

Material. Middle course of Gerbi River, h 700-900 m, pebble bank of river, 3-4.VII.1997, YS, 11 ex.

\section{Bembidion (Notaphus) obliquum Sturm, 1825}

Material. Lake Omot, h $1170 \mathrm{~m}$, silted shore, 915.VII.1997, YS, 26 ex.; ibid, 13-20.VII.1997, YS, 23 ex.; ibid, small lake among dwarf stone pine, 25.VI 2001, E. Novomodnyi leg., 4 ex. 


\section{Bembidion (Plataphodes) cf. crenulatum R.F. Sahlberg, 1844}

Material. Omot-Makit River from Lake Omot up to $3 \mathrm{~km}$ downstream, h 1050-1170 m, bank of the river, 512.VII.1997, YS, 2 ex.

Comment.Preliminary determination. 2 females were collected. The structure of the pronotum and other characters meke it possible to define them as $B$. crenulatum, but a distinct, slightly transverse microsculpture of the elytra brings them closer to B. fellmanni (Mannerheim, 1823).

\section{Bembidion (Plataphodes) difficile (Motschulsky, 1844)}

Material. Source of Omot River, h $1800 \mathrm{~m}$, snowfield edge on gravelly tundra, 14.VII.1997, YS, 7 ex.; the upper reaches of Urmi River, h 1700-2000 m, anonymous, 1 ex.

\section{Bembidion (Plataphus) cf. asiaticum Jedlička, 1965}

Material. Omot-Makit River from Lake Omot up to 3 $\mathrm{km}$ downstream, $\mathrm{h} \sim 1050-1170 \mathrm{~m}$, bank of the river, 12.VII.1997, YS, 17 ex.; Omot-Makit River 2 km below Lake Omot, h $1100 \mathrm{~m}$, bank of the river, 15-21.VII.1997, YS 31 ex

Comment. The definition was carried out according to the description of A. Jedlička [1965], since B. asiaticum is unknown to us.

\section{Bembidion (Plataphus) gebleri persuasum Netolitzky, 1938}

Material. Middle course of Gerbi River, h 700-900 m, pebble bank of river, 3-4.VII.1997, YS, 39 ex.; mouth of Omot-Makit River, h 900 m, pebble bank of river, 12.VII.1997, YS, 12 ex.

\section{Bembidion (Plataphus) infuscatipenne} Netolitzky, 1938

Material. Mouth of Omot-Makit River, h-900 m, pebble bank of river, 12.VII.1997, YS, 22 ex.

\section{Bembidion (Plataphus) prasinum} (Duftschmid, 1812)

Material. Mouth of Omot-Makit River, h 900 m, pebble bank of river, 12.VII.1997, YS, 5 ex.; Omot-Makit River from Lake Omot up to $3 \mathrm{~km}$ downstream, h 1050-1170 m, pebble bank of river, 6.VII.1997, YS, 7 ex.

\section{Bembidion (Terminophanes) mckinleyi scandicum Lindroth, 1943}

Material. Omot-Makit River $2 \mathrm{~km}$ below Lake Omot, $\mathrm{h} \sim 1100 \mathrm{~m}$, bank of the river, 21.VII.1997, YS, 4 ex.; source of Omot-Makit River from Lake Omot, h 1170 m, 13.VII.1997, YS, 2 ex.

\section{Patrobini Kirby, 1837}

Diplous (Platidius) depressus (Gebler, 1830)

Diplous (Platidius) dolini: Zamotajlov, 2005: 50 (environs of Dzhamku).

Diplous (Platidius) depressus (Gebler, 1829): Sundukov, 2013: 59 (Badzhal Range).

Material. Middle course of Gerbi River, h 700-900 m, pebble bank of river, 3-4.VII.1997, YS, 14 ex.; Omot-Makit River from Lake Omot up to $3 \mathrm{~km}$ downstream, h 10501170 m, 6.VII.1997, YS, 6 ex.; Omot-Makit River 2 km below Lake Omot, h $1100 \mathrm{~m}$, pebble bank of river, 15-21.VII.1997, YS, 16 ex.; Omot-Makit River from Omot Lake to the upper reaches, h 1170-1400 m, 7-9.VII.1997, YS, 1 ex.
Patrobus cinctus Motschulsky, 1860

Material. Omot-Makit River upstream of Omot Lake, h 1200-1250 m, bank of the river, 7.VII.1997, YS, 1 ex.

Platidiolus brinevi

Zamotajlov et Lafer, 2001

Platidiolus brinevi: Zamotajlov, Lafer, 2001: $432(40 \mathrm{~km}$ south of Mogdy, h 1800 m, alpica);

Zamotajlov, 2017: 465 (Badzhal Range).

Harpalinae Bonelli, 1810

Pterostichini Bonelli, 1810

Poecilus (Poecilus) fortipes

(Chaudoir, 1850) tion)

Poecilus fortipes Chd.: Shilenkov, 1987: 10 (Amgun sta-

Material. Lower course of Gerbi River, h $600 \mathrm{~m}$, on the road, 2.VII.1997, YS, 1 ex.

\section{Pterostichus (Bothriopterus) adstrictus Eschscholtz, 1823}

Material. Middle course of Gerbi River, h $700-900 \mathrm{~m}$, 3-4.VII.1997, YS, 1 ex.; $3 \mathrm{~km}$ above the mouth of OmotMakit River, h $1000 \mathrm{~m}$, dark coniferous valley forest, 5.VII.1997, YS, 1 ex;; Omot-Makit River from Lake Omot up to $3 \mathrm{~km}$ downstream, h 1050-1170 m, 6.VII.1997, YS, 1 ex.; Omot-Makit River $2 \mathrm{~km}$ below Lake Omot, h 1100 m, floodplain dark coniferous forest, 15-21.VII.1997, YS, 1 ex.; Lake Omot, h $1170 \mathrm{~m}$, floodplain dark coniferous forest, 915.VII.1997, YS, 2 ex.; Omot-Makit River from Omot Lake to the upper reaches, h 1170-1400 m, 7-9.VII.1997, YS, 2 ex.

\section{Pterostichus (Cryobius) amurensis} (Poppius, 1906)

Material. $3 \mathrm{~km}$ above the mouth of Omot-Makit River, h $1000 \mathrm{~m}$, dark coniferous valley forest, 5.VII.1997, YS, 8 ex.; Omot-Makit River $2 \mathrm{~km}$ below Lake Omot, h $1100 \mathrm{~m}$, floodplain dark coniferous forest, 15-21.VII.1997, YS, 8 ex.; Lake Omot, $\mathrm{h} \sim 1180 \mathrm{~m}$, larch forest at the foot of the slope, 8-13.VII.1997, YS, 10 ex.; ibid, h $1170 \mathrm{~m}$, floodplain dark coniferous forest, 13-20.VII.1997, YS, 54 ex.

Pterostichus (Cryobius) cf. brevicornis (Kirby, 1837)

Material. Source of Omot-Makit River, h -2000-2100 m, dwarf stone pine tundra, 7-19.VII.1997, YS, 36 ex.

Comment. Has not been studied in detail. The determination was made according to the publication of P. Erjiomin [1998].

\section{Pterostichus (Cryobius) kurosawai Tanaka, 1958}

Material. Middle course of Gerbi River at the mouth of Omot-Makit River, h 900 m, 4.VII.1997, YS, 1 ex.; 3 km above the mouth of Omot-Makit River, h $1000 \mathrm{~m}$, dark coniferous valley forest, 5.VII.1997, YS, 3 ex.; Omot-Makit River $2 \mathrm{~km}$ below Lake Omot, h $1100 \mathrm{~m}$, floodplain dark coniferous forest, 15-21.VII.1997, YS, 39 ex.; Omot-Makit River from Lake Omot up to $3 \mathrm{~km}$ downstream, h 1050$1170 \mathrm{~m}, 6 . V I I .1997$, YS, 3 ex.; the upper reaches of OmotMakit River, h 1400 m, 9.VII.1997, YS, 1 ex

\section{Pterostichus (Cryobius) cf. longipes (Poppius, 1906)}

Material. Source of Omot-Makit River, h 1800-2000 m, placer stones, 7-19.VII.1997, YS, 19 ex.; the upper reaches of Omot-Makit River, h 1400-1500 m, placer stones, 7.VII.1997, YS, 2 ex. 
Comment. Preliminary determination. A detailed comparison with beetles from the Siberian Arctic is required.

\section{Pterostichus (Cryobius) ochoticus (R.F.Sahlberg, 1844)}

Material. $3 \mathrm{~km}$ above the mouth of Omot-Makit River, h $1000 \mathrm{~m}$, dark coniferous valley forest, 5.VII.1997, YS, 7 ex. Omot-Makit River from Lake Omot up to $3 \mathrm{~km}$ downstream, h 1050-1170 m, 6.VII.1997, YS, 4 ex.; ibid, 12.VII.1997, YS, 4 ex.; Omot-Makit River 2 km below Lake Omot, h 1100 m, floodplain dark coniferous forest, 15-21.VII.1997, YS, 20 ex.; Lake Omot, h $1170 \mathrm{~m}$, floodplain dark coniferous forest, 915.VII.1997, YS, 63 ex.; ibid, 13-20.VII.1997, YS, 15 ex.; source of Omot-Makit River, h 1800-2000 m, mountain tundra, 7-19.VII.1997, YS, 24 ex.

\section{Pterostichus (Cryobius) cf. ventricosus (Eschscholtz, 1823)}

Material. $3 \mathrm{~km}$ above the mouth of Omot-Makit River, h $1000 \mathrm{~m}$, dark coniferous valley forest, 5.VII.1997, YS, 3 ex.; Omot-Makit River from Lake Omot up to $3 \mathrm{~km}$ downstream, h 1050-1170 m, 12.VII.1997, YS, 2 ex.; Lake Omot, h 1170 $\mathrm{m}$, floodplain dark coniferous forest, 9-15.VII.1997, YS, 41 ex.; ibid, 13-20.VII.1997, YS, 66 ex.

Comment. Preliminary determination. It differs from the nominative form by the structure of the pronotum, microsculpture of the elytra, the color of the palps, the structure of the penis lamella, which is close to the American Pt. riparius (Dejean, 1828), as well as its habitat in the forest.

\section{Pterostichus (Cryobius) sp. 1}

Material. $3 \mathrm{~km}$ above the mouth of Omot-Makit River, h $1000 \mathrm{~m}$, dark coniferous valley forest, 5.VII.1997, YS, 2 ex Lake Omot, h $1180 \mathrm{~m}$, larch forest at the foot of the slope, 8-13.VII.1997, YS, 9 ex.

Comment. Perhaps an undescribed species from the «ochoticus» species group. Similar to the description of Pt. (Cryobius) breviusculus (R.F. Sahlberg, 1844) [Sahlberg, 1844].

\section{Pterostichus (Cryobius) sp. 2}

Pterostichus (Cryobius) cf. sojot Shilenkov, 2000: Sundukov, 2013: 38 (Badzhal Range), 137 (source of the Omot-Makit River).

Material. Source of Omot-Makit River, h 1800-2000 m, mountain tundra, 7-19.VII.1997, YS, 6 ex.; the upper reaches of Omot-Makit River, h 1400-1500 m, placer stones, 79.VII.1997, YS, 6 ex.; source of Omot River (Urmi River basin), h 2000 m, tundra, 10-13.VII.2007, D. Kochetkov leg., 2 ex.

Comment. Probably an undescribed species close to the South Siberian Pt. homalonotus (Tschitschérine, 1894) or European Pt. negligens (Sturm, 1824).

\section{Pterostichus (Cryobius) sp. 3}

Material. Middle course of Gerbi River, h $700 \mathrm{~m}$ 3.VII.1997, YS, 2 ex.; ibid, mouth of Omot-Makit River, h $900 \mathrm{~m}$, 4.VII.1997, YS, 4 ex.; $3 \mathrm{~km}$ above the mouth of Omot-Makit River, h $1000 \mathrm{~m}$, dark coniferous valley forest, 5.VII.1997, YS, 3 ex.; Lake Omot, h $1180 \mathrm{~m}$, larch forest at the foot of the slope, 8-13.VII.1997, YS, 9 ex.; ibid, h 1170 $\mathrm{m}$, floodplain dark coniferous forest, 13-20.VII.1997, YS, 1 ex.; Omot-Makit River from Omot Lake to the upper reaches, h 1170-1400 m, 7-9.VII.1997, YS, 3 ex.

Comment. Probably an undescribed species from the «ochoticus» species group. It is close to Pt. kurosawai Tanaka, 1958, but noticeably smaller (length $6.5-7 \mathrm{~mm}$ ), with very narrow elytra, heart-shaped pronotum and finely punctured striae of elytra.

\section{Pterostichus (Cryobius) sp. 4}

Material. Source of Omot-Makit River, h 1800-2000 m, placer stones, 7-19.VII.1997, YS, 9 ex.; the upper reaches of Omot-Makit River, h 1400-1500 m, placer stones, 7.VII.1997, YS, 1 ex.

Comment. Undescribed species from the "planus" species group.

\section{Pterostichus (Eosteropus) orientalis \\ (Motschulsky, 1844)}

Material. Shore of Lake Omot at the source of OmotMakit River, h 1170 m, 12.VII.1997, YS, 2 ex.

\section{Pterostichus (Lenapterus) agonus G.H.Horn, 1880}

Material. Source of Omot-Makit River, h 1800-2000 m, mountain tundra, 7-19.VII.1997, YS, 3 ex.

\section{Pterostichus (Lenapterus) cancellatus}

(Motschulsky, 1860)

Pterostichus (Lenapterus) cancellatus (Motschulsky, 1860): Sundukov, 2005: 813 (Lake Omot; Omot-Makit River; Gerbi River; Dariya River).

Material. Middle course of Gerbi River at the mouth of Omot-Makit River, h 900 m, 4.VII.1997, YS, 2 ex.; $3 \mathrm{~km}$ above the mouth of Omot-Makit River, h $1000 \mathrm{~m}$, dark coniferous valley forest, 5.VII.1997, YS, 1 ex.; Omot-Makit River $2 \mathrm{~km}$ below Lake Omot, h 1100 m, floodplain dark coniferous forest, 15-21.VII.1997, YS, 4 ex.; Lake Omot, h $1170 \mathrm{~m}$, floodplain dark coniferous forest, 9-15.VII.1997, YS, 22 ex.; ibid, 13-20.VII.1997, YS, 18 ex.; ibid, 26.VI 2001, E. Novomodnyi leg., 5 ex.; ibid, Lake Omot, h $1180 \mathrm{~m}$, larch forest at the foot of the slope, 8-13.VII.1997, YS, 34 ex.; Omot-Makit River from Omot Lake to the upper reaches, h 1170-1400 m, 7-9.VII.1997, YS, 1 ex.; source of OmotMakit River, h 1800-2000 m, mountain tundra, 719.VII.1997, YS, 1 ex.; $30 \mathrm{~km}$ south of Mogdy station, h 500 m, larch-birch forest, 10-20.VII.1997, A. Brinev leg., 1 ex.; Dariya River, 7.IX 1965, O. Kabakov leg., 3 ex.

\section{Pterostichus (Lenapterus) saxicola}

(Tschitschérine, 1899)

Pterostichus (Lenapterus) saxicola (Tschitschérine, 1899): Sundukov, 2005: 809 (Lake Omot; Omot-Makit River; Gerbi River).

Material. Middle course of Gerbi River, h $700-900 \mathrm{~m}$, 3-4.VII.1997, YS, 2 ex.; Omot-Makit River $3 \mathrm{~km}$ above the mouth, h $1000 \mathrm{~m}$, valley coniferous forest, 5.VII.1997, YS, 2 ex:; Omot-Makit River $2 \mathrm{~km}$ below Lake Omot, $\mathrm{h} \sim 1100 \mathrm{~m}$, floodplain dark coniferous forest, 15-21.VII.1997, YS, 1 ex. Lake Omot, h $1170 \mathrm{~m}$, floodplain dark coniferous forest, 915.VII.1997, YS, 12 ex.; ibid, 26.VI 2001, E. Novomodnyi leg., 1 ex.; the upper reaches of Omot-Makit River, h 1180$1400 \mathrm{~m}$, dark coniferous forest, 7-9.VII.1997, YS, 2 ex.

\section{Pterostichus (Metallophilus) interruptus (Dejean, 1828)}

Material. Omot-Makit River $2 \mathrm{~km}$ below Lake Omot, h 1100 m, floodplain dark coniferous forest, 15-21.VII.1997, YS, 3 ex.; Omot-Makit River from Lake Omot up to $3 \mathrm{~km}$ downstream, h 1050-1170 m, 12.VII.1997, YS, 1 ex.; Lake Omot, h $1170 \mathrm{~m}$, placer stones by the lake, 9-15.VII.1997, YS, 2 ex.; the upper reaches of Omot-Makit River, $\mathrm{h} \sim 1400 \mathrm{~m}$, 9.VII.1997, YS, 1 ex.; $30 \mathrm{~km}$ south of Mogdy station, h 500 m, larch-birch forest, 10-20.VII.1997, A. Brinev leg., 2 ex. 


\section{Pterostichus (Petrophilus) eximius A. Morawitz, 1862}

Material. Omot-Makit River $2 \mathrm{~km}$ below Lake Omot, h $1100 \mathrm{~m}$, floodplain dark coniferous forest, 15-21.VII.1997, YS, 17 ex.; Lake Omot, h $1170 \mathrm{~m}$, floodplain dark coniferous forest, 9-15.VII.1997, YS, 38 ex.; ibid, 13-20.VII.1997, YS, 18 ex.; ibid, 25.VI.2001, E. Novomodnyi leg., 2 ex.; OmotMakit River from Omot Lake to the upper reaches, $\mathrm{h} \sim 1170-$ 1400 m, 7-9.VII.1997, YS, 4 ex.

\section{Pterostichus (Phonias) kutensis Poppius, 1905}

Material. Omot-Makit River $3 \mathrm{~km}$ above the mouth, h $1000 \mathrm{~m}$, valley coniferous forest, 5.VII.1997, YS, 3 ex.; Lake Omot, h $1180 \mathrm{~m}$, larch forest at the foot of the slope, 813.VII.1997, YS, 26 ex.; ibidem, h 1170 m, floodplain dark coniferous forest, 13-20.VII.1997, YS, 4 ex.

\section{Pterostichus (Pledarus) gibbicollis}

(Motschulsky, 1844)

Material. Lower course of Gerbi River, h $\sim 600-650 \mathrm{~m}$, forest glade, 2.VII.1997, YS, 1 ex.

\section{Pterostichus (Tundraphilus) orion bureianus Brinev, 2001}

Pterostichus (Tundraphilus) orion bureianus: Brinev, Shilenkov, 2001: 804 (source of the Omot-Makit River);

Sundukov, 2013: 130 (Badzhal Range).

Material. The upper reaches of Omot-Makit River, h 1500 m, placer stones, 7.VII.1997, YS, 1 ex.; source of Omot-Makit River, h 1800-2000 m, placer stones, 7-19.VII.1997, YS $10 \mathrm{ex}$

\section{Platynini Bonelli, 1810 Agonum (Agonum) bicolor (Dejean, 1828)}

Material. Gerbi River valley $2-5 \mathrm{~km}$ below the mouth of Omot-Makit River, h 850-900 m, 4.VII.1997, YS, 6 ex.; 3 km above the mouth of Omot-Makit River, h $1000 \mathrm{~m}$, dark coniferous valley forest, 5.VII.1997, YS, 24 ex.; Omot-Makit River from Lake Omot up to $3 \mathrm{~km}$ downstream, h 1050$1170 \mathrm{~m}$, valley coniferous forest, 6.VII.1997, YS, 1 ex.; ibid, 12.VII.1997, YS, 14 ex.; Lake Omot, h 1170 m, floodplain dark coniferous forest, 9-15.VII.1997, YS, 8 ex.; ibid, 1320.VII.1997, YS, 1 ex.

\section{Agonum (Europhilus) thoreyi Dejean, 1828}

Material. Lake Omot, h $1170 \mathrm{~m}$, silted shore, 915.VII.1997, YS, 3 ex.

\section{Agonum (Olisares) dolens \\ (C.R. Sahlberg, 1827)}

Material. Middle course of Gerbi River, h $700-800 \mathrm{~m}$, bank of the river, 3.VII.1997, YS, 2 ex.; Lake Omot, h 1170 m, silted shore, 9-15.VII.1997, YS, 4 ex.

\section{Agonum (Olisares) impressum \\ (Panzer, 1796)}

Material. Lower course of Gerbi River, h $600-650 \mathrm{~m}$, bank of the river, 2.VII.1997, YS, 1 ex.

\section{Sericoda quadripunctata}

(DeGeer, 1774)

Material. Source of Omot River (Urmi River basin), h $2000 \mathrm{~m}$, tundra, 10-13.VII.2007, D. Kochetkov leg., 1 ex.
Zabrini Bonelli, 1810

Amara (Amara) anxia Tschitschérine, 1898

Material. Source of Omot-Makit River, h 1800-2000 m, mountain tundra, 7-13.VII.1997, YS, 4 ex.; ibid, 1419.VII.1997, YS, 1 ex.

\section{Amara (Amara) communis (Panzer, 1796)}

Material. Lower course of Gerbi River, h $600-650 \mathrm{~m}$, bank of the river, 2.VII.1997, YS, 1 ex.

\section{Amara (Amara) kingdonoides Hieke, 2002}

Material. Omot-Makit River from Omot Lake to the upper reaches, h 1170-1400 m, 7-9.VII.1997, YS, 5 ex; source of Omot-Makit River, h 2000-2100 m, dwarf stone pine tundra, 7-19.VII.1997, YS, 3 ex.

Amara (Amara) lunicollis Schiødte, 1837

Material. Lower course of Gerbi River, h $600-700 \mathrm{~m}$, road in the larch forest, 2.VII.1997, YS, 2 ex.; middle course of Gerbi River, h 700-900 m, bank of the river, 3-4.VII.1997, YS, 3 ex

\section{Amara (Celia) brunnea (Gyllenhal, 1810)}

Material. $3 \mathrm{~km}$ above the mouth of Omot-Makit River, h $1000 \mathrm{~m}$, dark coniferous valley forest, 5.VII.1997, YS, 2 ex.; Omot-Makit River $2 \mathrm{~km}$ below Lake Omot, h 1100 m, floodplain dark coniferous forest, 15-21.VII.1997, YS, 9 ex.; Lake Omot, h $1170 \mathrm{~m}$, floodplain dark coniferous forest, 915.VII.1997, YS, 7 ex.

Harpalini Bonelli, 1810

Harpalus (Harpalus) affinis (Schrank, 1781)

Material. Lower course of Gerbi River, h $600-650 \mathrm{~m}$, on the road, 2.VII.1997, YS, 1 ex.

\section{Harpalus (Harpalus) laevipes Zetterstedt, 1828}

Material. Lake Omot, h $1170 \mathrm{~m}$, floodplain dark coniferous forest, 9-15.VII.1997, YS, 1 ex.; ibid, 1320.VII.1997, YS, 2 ex

Lebiini Bonelli, 1810

Cymindis (Baicalotarus) collaris Motschulsky, 1844

Cymindis (Baicalotarus) collaris (Motschulsky, 1844): Sundukov, 2011: 336 (Amgun River near Beresovy).

Material. Lower course of Gerbi River, h 600-650 m, on the road, 2.VII.1997, YS, 1 ex.

\section{Cymindis (Tarulus) vaporariorum (Linnaeus, 1758)}

Cymindis (Tarus) vaporariorum (Linnaeus, 1758): Sundukov, 2011: 340 (source of the Omot-Makit River; $30 \mathrm{~km}$ south of Mogdy).

Material. Source of Omot-Makit River, h 2000-2100 m, dwarf stone pine tundra, 7-19.VII.1997, YS, 1 ex.; $30 \mathrm{~km}$ south of Mogdy station, h $500 \mathrm{~m}$, larch-birch forest, 1020.VII.1997, A. Brinev leg., 3 ex.

\section{Conclusion}

In total, in our article about the Badzhal Range, 76 species, 21 genera, and 15 tribes of Carabidae are indicated. Of them, 68 species from 19 genera and 15 tribes were found directly in the mountains (zones of mountain forests and mountain tundra). 
The statistics of our collections in the Omot-Makit River basin (1846 specimens from 63 species, 18 genera, 15 tribes) shows that the tribe Pterostichini (19 species, 734 ex.) clearly dominates in the number of species and specimens both in the forest and in the tundra. Tribes Nebriini (9 species, 391 ex.), Bembidiini (11 species, 173 ex.) and Carabini ( 5 species, 270 ex.) are also richly represented.

In the mountain forest zone, at altitudes of 900$1600 \mathrm{~m}$, representatives of the genus Pterostichus dominate (13 species, 614 ex.). Ground beetles of the genera Bembidion (10 species, 176 ex.), Nebria (7 species, 353 ex.), Carabus (3 species, 118 ex.), Notiophilus (1 species, 67 ex.), and Agonum (3 species, 61 ex.) are also numerous.

The same situation is observed in the mountaintundra zone, at altitudes of 1500-2100 m, where the most common species of the genera Pterostichus ( 8 species, 120 ex.), Carabus (4 species, 152 ex.), Nebria (3 species, 23 ex.) and Notiophilus (1 species, 24 ex.).

Moreover, in all zonal biotopes of the Omot-Makit River basin the most numerous are ground beetles of the subgenus Cryobius of the genus Pterostichus, which make up $22 \%$ of the species diversity and $31 \%$ of the collected specimens in the mountain tundra, $12 \%$ and $25 \%$ in the mountain forests, and in general in the Omot-Makit River basin - $16 \%$ and $26 \%$, respectively.

Thus, at the level of the tribal groups of the carabidofauna of the Badzhal Range, it has pronounced features of the arctomontane fauna in the understanding of O.L. Makarova et al. [2013], enriched with a significant proportion of East Asian boreomontane endemic species.

\section{Acknowledgements}

We thank Evgeny V. Novomodnyi (Khabarovsk), Denis N. Kochetkov (Arkhara, Amurskaya oblast') and Alexey E. Brinev (Moscow) for providing interesting material for this study. We are also grateful to Andrei V. Plutenko (Smolensk) for photos from our 1997 campaign.

\section{References}

Brinev A.E., Budilov P.V. 2007. Nekotorye zakonomernosti biotopicheskogo raspredeleniya Carabus (Aulonocarabus) gaschkewitchi v gorakh Vostochnoy Sibiri i Dal'nego Vostoka // Materialy mezhdunarodnoy nauchno-prakticheskoy konferencii «Okhrana i nauchnye issledovaniya na osobo okhranyaemykh prirodnykh territoriyakh Dal'nego Vostoka i Sibiri», posvyashchennoy 20-letiyu organizacii Bureinskogo gosudarstvennogo prirodnogo zapovednika (p. Chegdomyn, 10-12 avgusta 2007 g.). Khabarovsk: Priamurskoe geograficheskoe obshchestvo. P.27-29. [In Russian].

Brinev A.E., Shilenkov V.G. 2001. Ground beetles of subgenus Tundraphilus of Pterostichus genus (Coleoptera, Carabidae) // Zoologicheskiy Zhurnal. Vol.80. No.7. P.797-808. [In Russian].

Deuve Th., Reuter Ch. 2019. Trois nouveaux Carabus L., 1758, de Sibérie et du Sichuan (Coleoptera, Carabidae) // Coléoptères. Vol.25. No.1. P.1-8.
Dudko R.Yu. 2006. A revision of the Palaearctic species of the subgenus Catonebria Shilenkov, 1975 (Coleoptera, Carabidae, Nebria). 2. Nebria catenulata - species group // Euroasian Entomological Journal. Vol.5. No.1. P.17-46+I-III. [In Russian].

Erjiomin P.K. 1998. Vidy gruppy Pterostichus (Cryobius) brevicornis (Coleoptera, Carabidae) Palearktiki // Zoologicheskiy Zhurnal. Vol.77. No.3. P.295-302. [In Russian].

Gvozdecki N.A., Golubchikov Yu.N. 1987. [The Mountains. Series: Nature of the World]. M.: Mysl'. 399 p. [In Russian].

Jedlička A. 1965. Neue Carabiden aus den Sammlungen des Staatlichen Museums in Dresden // Reichenbachia. Bd.6. Nr.6. S.73-77.

Koshkin E.S., Rogatnykh D.Yu., Bezborodov, V.G. 2016. Ground beetles (Coleoptera: Carabidae) of the Bureinskii State Nature Reserve, Khabarovskii Krai, Russia // Euroasian Entomological Journal. Vol.15. No.4. P.309-318. [In Russian].

Lafer G.Sh. 1978. Obzor zhukov-skakunov (Coleoptera, Carabidae) Dal'nego Vostoka SSSR // Ivliev L.A. (Ed.): Biologiya nekotorykh vidov vrednykh i poleznykh nasekomykh Dal'nego Vostoka. Vladivostok: Dalnauka. P.3-18. [In Russian].

Lafer G.Sh. 1989. 4. Semeystvo Carabidae - Zhuzhelitsy // Lehr P.A. (Ed.): Opredelitel nasekomykh Dalnego Vostoka SSSR. Tom 3. Zhestkokrylye, ili zhuki. Chast 1. Leningrad: Nauka. P.71-222. [In Russian].

Makarova O.L., Makarov K.V., Berman D.I. 2013. Ground beetles (Coleoptera, Carabidae) of the Ola Plateau highlands, Kolyma Uplands // Zoologicheskiy Zhurnal. Vol.92. No.8. P.927-934. [In Russian].

Man'ko Yu.I. 1961. [Kratkiy ocherk lesnoy rastitel'nosti verkhney poloviny basseyna reki Urmi] // Komarovskie chteniya. Vol.9. P.42-71. [In Russian].

Mishina N.V. 2003. Transgranichnye geosistemy yuga rossiyskogo Dal'nego Vostoka. Vladivostok: TIG DVO RAN. 64 p. [In Russian].

Obydov D. 1999. Review of the Megodontus group of the genus Carabus Linné of Sibiria. (Coleoptera: Carabidae) // Coleoptera, Schwanfelder Coleopterologische Mitteilungen. Bd.3. S.83-130.

Obydov D. 2005. Faune des Carabus de Sibérie et d'ExtrêmeOrient russe - II Neocarabi // Magellanes, Collection Systématique. Vol.11. P.1-134, 1-22 pls.

Plutenko A.V. 2004. New data on species of the genus Trechus (Coleoptera, Carabidae) in the Russian Far East // Euroasian Entomological Journal. Vol.3. No.1. P.3336. [In Russian].

Sahlberg R.F. 1844. In faunam insectorum Rossicam symbola, novas ad Ochotzk lectas carabicorum species continens // Acta Societatis Scientiarum Fennicae, Vol.3. P.1-66.

Sundukov Yu.N. 2005. A review of the species of the subgenus Lenarterus (Coleoptera, Carabidae, Pterostichus) with description of new species and subspecies from the SikhoteAlin Mountains // Zoologicheaskiy Zhurnal. Vol.84. No.7. P.803-825. [In Russian].

Sundukov Yu.N. 2011. A review of the genus Cymindis Latreille, 1806 (Coleoptera, Carabidae, Lebiini) of East Asia // Amurian zoological journal. Vol.3. No.4. P.315344. [In Russian].

Sundukov Yu.N. 2013. An annotated catalogue of the ground beetles (Coleoptera: Caraboidea) of Sikhote-Alin. Vladivostok: Dalnauka. 271 p. [In Russian].

Sundukov Yu.N. 2019. The main stages in the formation of the ground beetle fauna (Coleoptera, Carabidae) of the Sikhote- 
Alin', endemics taken as an example. 2. An analysis of distributions // Zoologicheskiy Zurnal. Vol.98. No.9. P.10481062. [In Russian].

Shilenkov V.G. 1987. Materialy po faune zhuzhelits (Coleoptera, Carabidae) // Rozhkov A.S. (Ed.): Nasekomye zony BAM. Novosibirsk: Nauka. P.6-15. [In Russian].

Zamotajlov A.S. 2005. A new species of the genus Diplous, subgenus Platidius (Coleoptera, Carabidae) from East Siberia // Vestnik zoologii. Vol.39. No.1. P.47-54.
Zamotailov A.S. 2017. Subfamily Patrobinae Kirby, 1837 // Löbl I., Löbl D. (Eds): Catalogue of Palaearctic Coleoptera. Volume 1. Archostemata-Myxophaga-Adephaga. Revised and Updated Edition. Volume 1. Leiden-Boston: Brill. P.456-465.

Zamotajlov A.S., Lafer G.Sh. 2001. Contribution to the knowledge of the carabid genus Platidiolus Chaudoir, 1878 (Coleoptera, Carabidae) from continental Asia // Entomologicheskoe Obozrenie. Vol.80. No.2. P.411-435. [In Russian]. 